IJBPAS, December, Special Issue, 2021, 10(12): 363-373

ISSN: 2277-4998

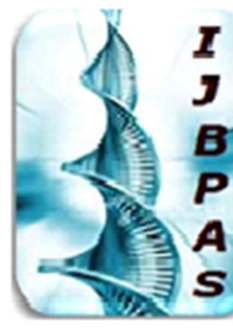

International Journal of Biology, Pharmacy

and Allied Sciences (IJBPAS)

'A Bridge Betueen caboratory and QRendo'

Www.jibpas.com

FIELD SURVEY AND ISOLATION OF MICROFLORA FROM FISH

Clarius batrachus

\author{
S. A. MANKAR AND A. M. CHANDAK* \\ Department of Microbiology, Dada Ramchand Bakhru Sindhu Mahavidhyalaya, Nagpur
}

*Corresponding Author: A. M. Chandak: E Mail: anitamchandak@gmail.com

Received 19 ${ }^{\text {th }}$ Aug. 2021; Revised $20^{\text {th }}$ Sept. 2021; Accepted $29^{\text {th }}$ Oct. 2021; Available online $1^{\text {st }}$ Dec. 2021

https://doi.org/10.31032/IJBPAS/2021/10.12.2034

\begin{abstract}
The beneficial and harmful microorganisms present in the gastrointestinal (GI) tract of fish. Microflora in the gastrointestinal tract of fish is vital role for healthy living of it. It is stated by many researchers that only few microorganisms spp. present in water are belongs to microflora in the gastrointestinal tract. Few of these spp. acclimatizes themselves in GI tract, whereas the remaining microorganisms are processed by digestive enzymes secreted by fish. The molecular approach provides a more complete picture about bacterial community composition than do cultured based methods. Application of Molecular identification based on 16srDNA gene by using Polymerase Chain Reaction (PCR). 16S r DNA approach has been successfully applied to determine the bacterial diversity present in GI of fish. In the present research work, the study of molecular characterization of microflora helps in some or another way for understanding the risk associated with pathogenic and non-pathogenic organisms and it will also help to study the common contaminants of water isolated from the intestine of Clarius batrachus for further research in aquaculture pathology.
\end{abstract}

Keywords: Fish, 16srDNA, PCR

\title{
INTRODUCTION
}

Microflora is not only essential but also vitally important component of the digestive tract in animals including fish. The community of microorganism in the digestive tract of fishes is analogous to that in mammals, since the cell structure of the intestine and physiology of digestion in mammals and fish are similar in some extent $[1,2]$. Gut flora have a continuous and dynamic effect on the host's gut and 
systemic immune systems. The bacteria are important in promoting the early development of the gut's mucosal immune system both in terms of its physical components and function and continue to play a role later in life in its operation. The bacteria stimulate the lymphoid tissue associated with the gut mucosa to produce antibodies to pathogens. The gastrointestinal tract microflora of freshwater fish has been investigated by many researchers during last decade $[3,4$, 5 , 6]. These microflora's have been identified on the basis of morphological, culture based method and Molecular characterization. The alimentary tract of fish represents an interface between the external environment and the body. Its complex polymicrobial ecology interacts with the internal and external environmental and has an important influence on health and diseases. The intestine is a complex multifunctional organ; in addition to digesting and absorbing feedstuff, it is critical for water and electrolyte balance, endocrine regulation of digestion, metabolism and immunity. The GI tract of freshwater fish is a complex ecosystem, containing a large quantity of microorganisms more than those in the habitat water, defined by population inclusive diversity and their difficulty of interaction $[7,8]$. The GI microflora holds antibacterial activity against large number of fish pathogens and contributes in infection -protective activity [9].

$$
\text { It is stated by many }
$$

researchers that numerous fresh water fish have confirmed bacteria in the GI lumen and related with the epithelium $[1,10]$. The GI microflora has play main and definite metabolic, tropic and defensive function. The regular microflora of the GI tract participate in many helpful activity to the intestinal functioning of the host $[11,12]$. Some of these benefits include the metabolism of nutrients, contribution of the colonization resistance, antagonistic activity against pathogens, etc. The enzyme producing microflora can be beneficially used as probiotic supplements while formulating the fish diet especially in the larval stage. According to many author [13, 14] fish health problem and socioeconomic impact of diseases in inland and freshwater water culture-based fisheries are directly related with depending on feeding habits and diet of fish. The variation in morphology of the GI and type of food which is important for composition and activity of the fish GI microflora [9]. 


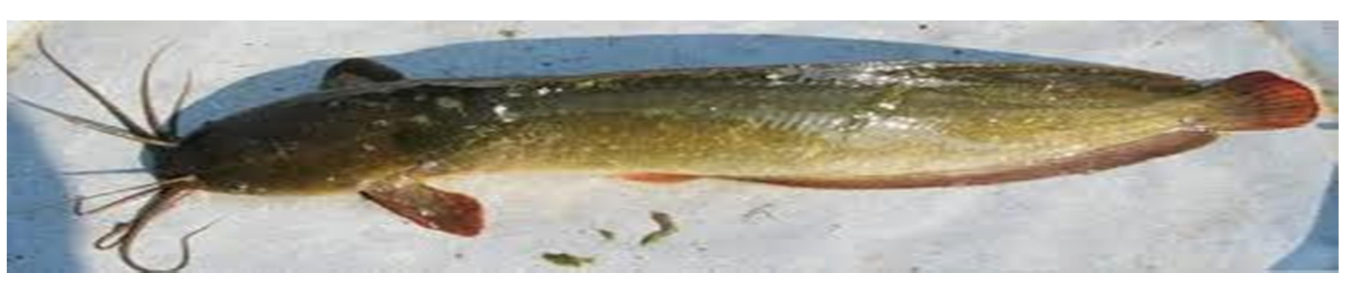

Figure 1: Clarius batrachus

It is stated by many researchers like Carl Woese and George E. Fox who pioneered the application of $16 \mathrm{~S}$ rRNA in phylogenies. Many studies of $16 \mathrm{~S}$ rRNA gene sequences for large number of bacteria and archaebacteria are accessible on NCBI. However, the some of the sequences originate on these databases are often not authenticated. Experiments using Molecular identification founded on 16srDNA phylogenetics with PCR methods facilitates identification and evaluation of the GI microflora of fish and also gives a phylogenetic scheme to predict relationship between microbe-microbe and hostmicrobe collaboration in strength and diseases [15]. The goal of present study was to collect representative fish from different lakes, river, and test their tissues for specific fish pathogens and to find out the important role of beneficial microorganisms as Microflora in diseases. Molecular approaches have emerged in microbiology practices. Their high sensitivity, specificity and the short time required to perform the procedure defines the great interest given to these techniques in microbiological research while rapid and accurate identification of bacterial isolates provides insights into etiologies of pathogens.

Only live and healthy fish (Clarius batrachus) were collected using aseptic techniques and packed in coolers with ice for immediate transfer to the laboratory. The Present study were representing that sample were collected from in and around Nagpur city. Isolates were isolated from gut of fish and after DNA extraction of these isolates were further investigated for $16 \mathrm{~s}$ rDNA analysis using PCR.

\section{METHODS AND MATERIALS:}

1. Field survey and collection of samples from Nagpur district

The most important lakes and tanks in the district from fisheries point of view are tanks several small perennial tanks at Katol, Umrer, Bhivapur, Kuhi, Bhojapur, Bazargaon and Gumgaon, where fish culture is being undertaken either in public or in private sector.

Field and laboratory course focusing on the physical and biological survey of aquatic ecosystems. As per schedule spend at a remote lake conducting a series of survey activities. The resulting data are analysed in a field laboratory and during weekly/sometime monthly field survey 
taken out. Nag River which is a branch of Kanhan takes its origin from Ambazari and flows towards east through Nagpur city. The Nag River water is completely polluted on account of draining of sewage and effluents into it. Lakes and rivers are major water resource found in vidharbha region. Some of these are used to supply water for drinking purpose like Gorewada lake and Wena tank.

In the present research investigation, samples from field surveys were collected and kept in aquarium to analyze further examination in the laboratory. Samples were taken from fish and then immersed in Bovin's fixative for overnight and GI were removed and sap collected in the phosphate buffer for the further research i.e., light and scanning electron microscopy study of isolated microflora then later on for the identification of microflora by using morphological and biochemical characterization, cultural characterization and antibiotic sensitivity test of respective isolates.

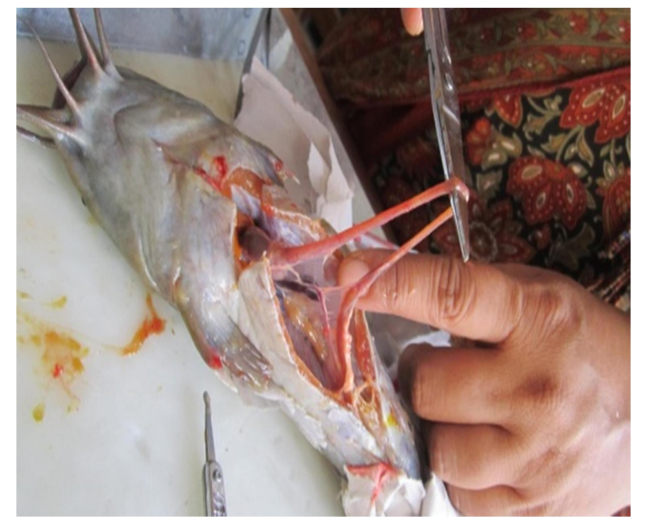

Figure 2: Dissections of fish Clarius batrachus (Extraction of Gut)
2. Light and scanning electron microscopy study of isolated microfloraTrinocular Phase contrast microscope (Make -Carl Zeiss, model - Primostar) with Digital camera (Make-Canon G12 Powershot) attached lens adapter (Make-Carl Zeiss) for the said Camera financed by UGC during present research project.

3. Identification of Microflora by using Morphological and Biochemical characterization, cultural

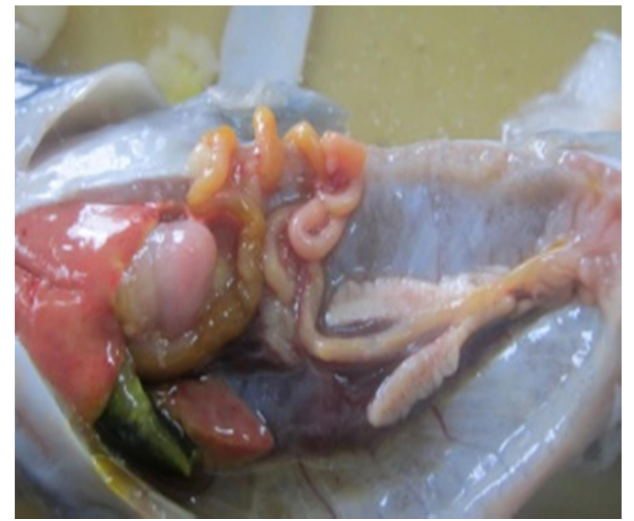

characterization and Antibiotic sensitivity test of respective isolates.

4. Isolation of respective DNA from isolates

DNA was isolated from the liquid culture.

Electrophoresed in a 1\% Agarose gel and visualized under UV

5. PCR condition and amplification:

Prominent isolates Aeromonas sp., Vibrio sp. Pseudomonas sp. Bacillus sp., Delftia 
sp. Stenotrophomonas sp., E.coli, E. aerogens, Streptococcus sp. , etc. Few of them, as a representative of genus group were procured for 16srDNA PCR analysis. The 16S rRNA gene sequence is large and composed of both variable and conserved regions.

The gene is large enough, with enough interspecific polymorphisms of $16 \mathrm{~S}$ rRNA sequence, to offer distinctive and statistically effective data.

\section{RESULT AND CONCLUSION -}

On the basis of preliminary data of presumptive spp. based on morphological and biochemical characterization, cultural characterization collected, the screening and investigations of bacterial isolates were done to assess and identify the types of bacterial pathogens on the basis of Gram staining, motility and different cultural characteristics and thus revealed the occurrence of prominent isolates Aeromonas sp., Vibrio sp. Pseudomonas sp. Bacillus sp., Delftia sp. Stenotrophomonas sp., E.coli, E. aerogens, Streptococcus sp., etc. and some fungal colonies as found on selective media plate of respective organisms (Table 1).
Almost all isolates are sensitive to broad spectrum antibiotic sensitivity test and showing significant zone of inhibition against Norfloxacin, Nalidixic acid CoTrimoxazole; Pipemidic acid \& Cefuroxime showing intermediate result against isolates while isolates mostly showing resistant or there is no zone inhibition against ampicillin (Figure 3).

The experiments were performed and various parameters such as, morphological, biochemical (Figure 2), and cultural characteristics (Figure 1); DNA extraction and molecular characterization from isolated strains were done. On the basis of morphological, biochemical, cultural characteristics, there were prominent isolates Aeromonas sp., Vibrio sp. Pseudomonas sp. Bacillus sp., Delftia sp. Stenotrophomonas sp., E.Coli, E.aerogens, Streptococcus sp., etc. Few of them, as a representative of genus group were procured for 16srDNA PCR analysis. The sequence analysis ware carried out using bioinformatics tool BLAST of NCBI and dendrogram were constructed. 
Table 1: Identification of Microflora by using Morphological and Biochemical characterization, cultural

\begin{tabular}{|c|c|c|c|c|c|c|c|c|c|c|}
\hline Genus Group & $\begin{array}{c}\mathrm{A} \\
\text { Steno }\end{array}$ & $\underset{\text { Bacillus }}{\text { AH }}$ & $\begin{array}{c}\mathbf{E} \\
\text { E.col }\end{array}$ & $\begin{array}{c}\text { SK } \\
\text { Delftia }\end{array}$ & $\begin{array}{c}\mathbf{R} \\
\text { E.aero }\end{array}$ & $\begin{array}{c}\text { S } \\
\text { Strept }\end{array}$ & $\begin{array}{c}\text { SM } \\
\text { Pseudo }\end{array}$ & $\begin{array}{c}\text { H } \\
\text { Aero }\end{array}$ & $\begin{array}{c}\mathrm{V} \\
\text { Vibrio }\end{array}$ & $\begin{array}{c}\mathrm{U} \\
\text { unk }\end{array}$ \\
\hline Biochemical Tests & & & & & & & & & & \\
\hline Gram-staining & - & + & - & - & - & + & - & - & - & - \\
\hline Shape & Rod & Rod & $\begin{array}{c}\text { Small } \\
\text { rod }\end{array}$ & $\begin{array}{l}\text { Short } \\
\text { Rod }\end{array}$ & Rod & Cocci & Rod & Rod & Rod & Rod \\
\hline Motility & + & - & + & + & - & - & + & + & + & + \\
\hline Oxygen uptake & $\mathbf{A}$ & $\mathbf{A}$ & $\mathbf{F}$ & $\mathbf{A}$ & $\mathbf{F}$ & $\mathbf{F}$ & $\mathbf{O A}$ & $\mathbf{F}$ & $\mathbf{F}$ & $\mathbf{O A}$ \\
\hline Growth at $28^{\circ} \mathrm{C}$ & + & + & + & + & + & + & + & + & + & + \\
\hline $37^{\circ} \mathrm{C}$ & + & + & + & + & + & + & + & + & + & + \\
\hline Glucose AG & - & & AG & - & $\mathbf{A}$ & $\mathbf{A}$ & AG & AG & AG & AG \\
\hline Lactose AG & - & & AG & - & $\mathbf{A}$ & - & AG & - & & - \\
\hline Oxidase & - & + & & + & - & - & + & + & + & + \\
\hline Catalase & + & + & & + & + & - & + & + & - & $+/-$ \\
\hline Urea hydrolysis & ND & - & ND & - & ND & - & ND & - & - & + \\
\hline Indole Production & $+/-$ & & + & - & - & + & - & $-/+$ & $+/-$ & $+/-$ \\
\hline Methyl red & + & - & + & + & - & + & + & - & - & - \\
\hline $\begin{array}{c}\text { Voges-Proskauer } \\
\text { test }\end{array}$ & - & $+/-$ & - & - & + & + & - & $+/-$ & + & + \\
\hline Citrate & - & - & - & + & + & - & $+/-$ & + & - & - \\
\hline Esculin hydrolysis & - & - & - & - & - & - & - & + & - & - \\
\hline Cetrimide agar & ND & ND & ND & ND & ND & ND & + & ND & ND & ND \\
\hline $\begin{array}{c}\text { Bacillus isolation } \\
\text { agar }\end{array}$ & - & + & - & - & - & - & - & - & + & - \\
\hline BHI & ND & ND & ND & ND & ND & + & ND & + & ND & ND \\
\hline $\begin{array}{l}\text { Streptococcus } \\
\text { selective agar }\end{array}$ & - & - & - & - & - & + & - & - & - & - \\
\hline $\begin{array}{c}\text { Rimpler-Shotts } \\
\text { Media }\end{array}$ & ND & ND & ND & ND & ND & ND & ND & + & ND & ND \\
\hline $\begin{array}{c}\text { Aeromonas } \\
\text { Selective agar }\end{array}$ & ND & ND & ND & ND & ND & ND & ND & + & ND & ND \\
\hline Nutrient agar & + & + & + & + & + & + & $\begin{array}{c}+ \\
\text { Pigment } \\
\end{array}$ & + & $\begin{array}{c}+ \\
(\mathrm{NaCl}) \\
\end{array}$ & + \\
\hline TCBS & - & - & - & - & - & - & ND & - & + & - \\
\hline MacConkey agar & $\begin{array}{c}+ \\
\text { Pale }\end{array}$ & ND & $\begin{array}{c}+ \\
\text { Pink }\end{array}$ & + & ND & ND & + & - & ND & ND \\
\hline
\end{tabular}

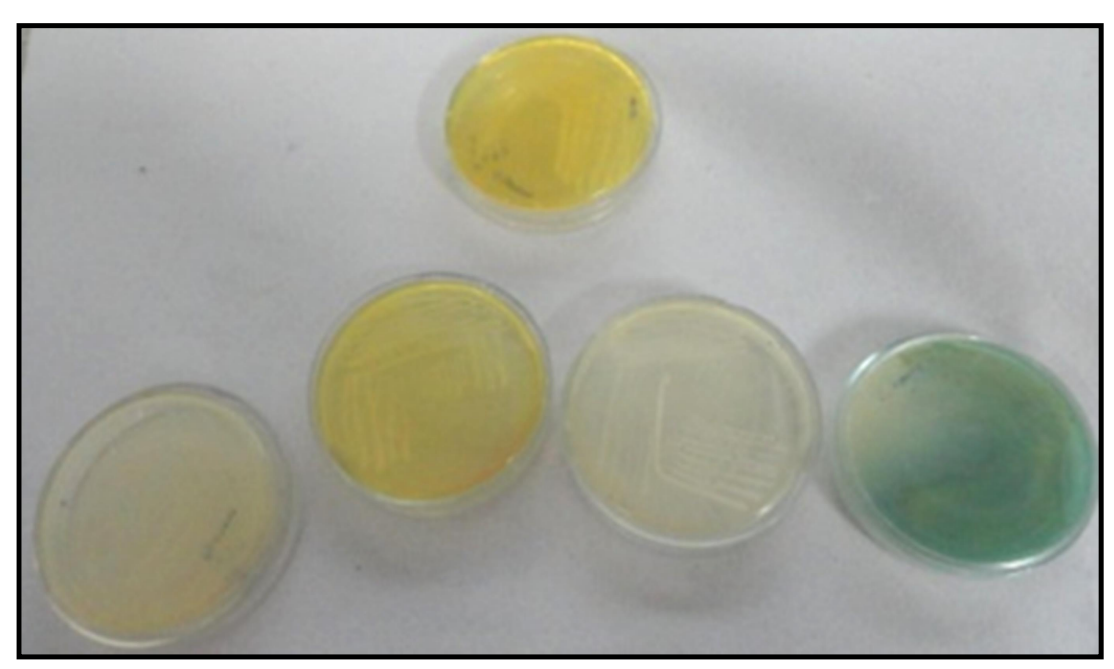

(3a) 


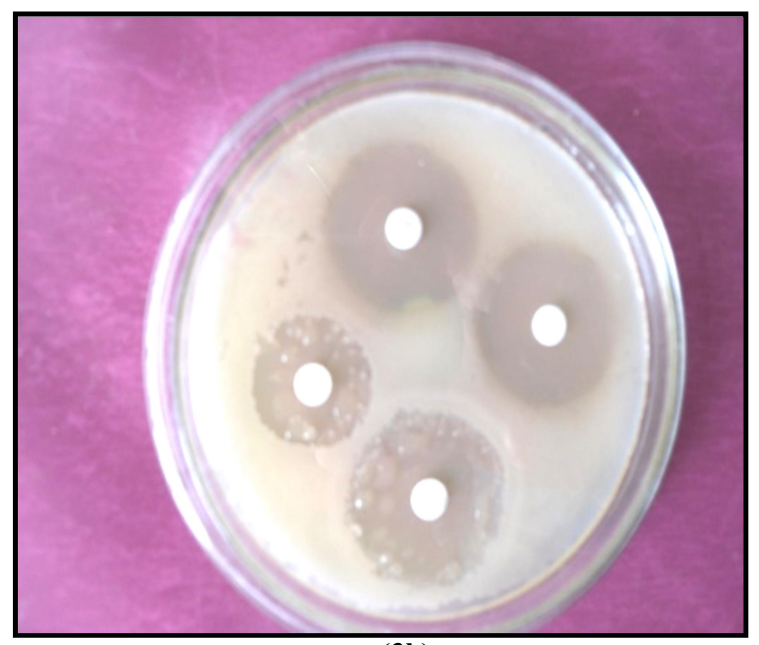

(3b)

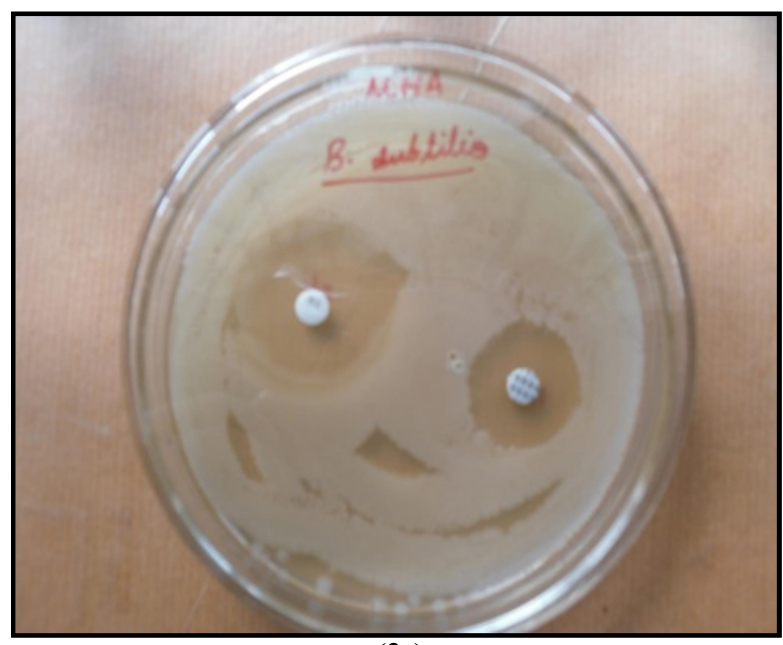

(3c)

Figure 3: Above Figure showing colonies on Selective agar media plates and below figure showing antibiotic sensitivity test on Muller-Hinton agar

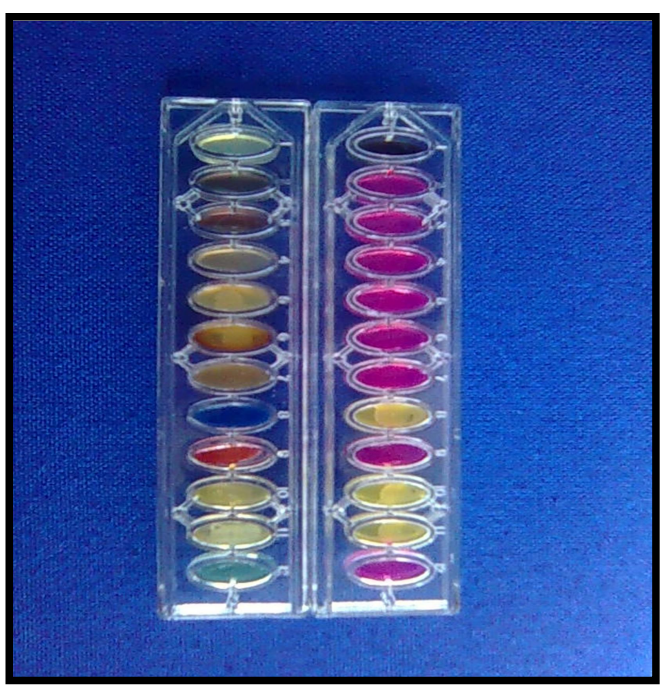

Figure 4: Demontration of series of biochemical tests (Himedia Kit)

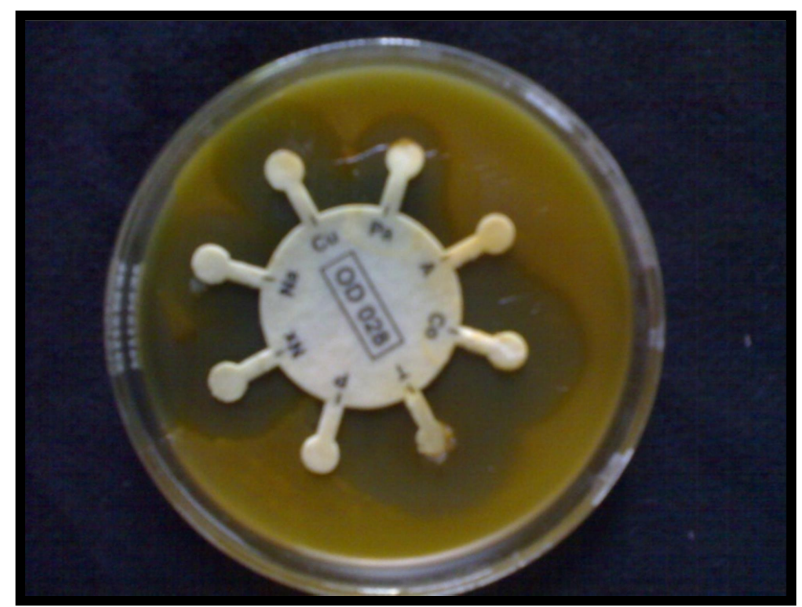

Figure 5: Antibiotic sensitivity test against selected Aeromonas spp.using Octadisc $($ Himedia $)(\mathrm{A}=\mathrm{Ampicillin}, \mathrm{Co}=\mathrm{Co}-$ Trimoxazole, $\mathrm{T}=$ Tetracycline $=$ Penicillin, $\mathrm{Nx}=$ Norfloxacin, $\mathrm{Na}=$ Nalidixic acid, $\mathrm{Cu}=$ Cefuroxime, $\mathrm{Pa}=$ Pipemidic acid) 
The isolated were found significant similarity with Delftia tsuruhatensis, Pseudomonas fluorescens based on nucleotide homology and phylogenetic analysis. 16S rDNA gene sequencing had a large accuracy as related to the other experimental methods. The obtained results suggest that combination of conventional methods and 16S rDNA gene sequencing provide a more accurate identification of Microflora as bacteria to enhance the fish health management.

Phylogenetic Tree (SK1): Molecular identification based on 16s rDNA gene by using PCR technique

Procedure to standardized the lab protocol for Molecular identification based on 16 s rDNA gene by using PCR technique were failed to evaluate the result However, later on to fulfill remaining last objective, the efforts were made by executing different protocols of methodology but the end result were frivolous and found to be extravagant. While optimizing the same, Samples were procured for service.

16s rDNA gene was PCR amplified with $16 \mathrm{~s}$ forward and $16 \mathrm{~s}$ reverse primers.
Amplicon was electrophoresed in a $1 \%$ Agarose gel and visualized under UV Concentration of the amplicon was checked. The amplicon was purified using Nucleospin purification column Forward and reverse sequences were assembled and contig was generated after trimming the low quality bases. The sequence analysis was carried out using bioinformatic tool BLAST of NCBI.

Based on maximum identity score first few sequences were selected and aligned using multiple sequence alignment software MultAlin. Dendrogram was constructed.

Finally, the interpretation of sequences depends on the basis of blast report, NCBI database, multiple sequence alignment result and phylogenetic dendogram, "SK1"Delftia tsuruhatensis (Figure 6, 7) as representative of genus group based on nucleotide homology and phylogenetic analysis. "AH2"- Bacillus cereus; "SM" shows significant similarity with Pseudomonas fluorescens; 

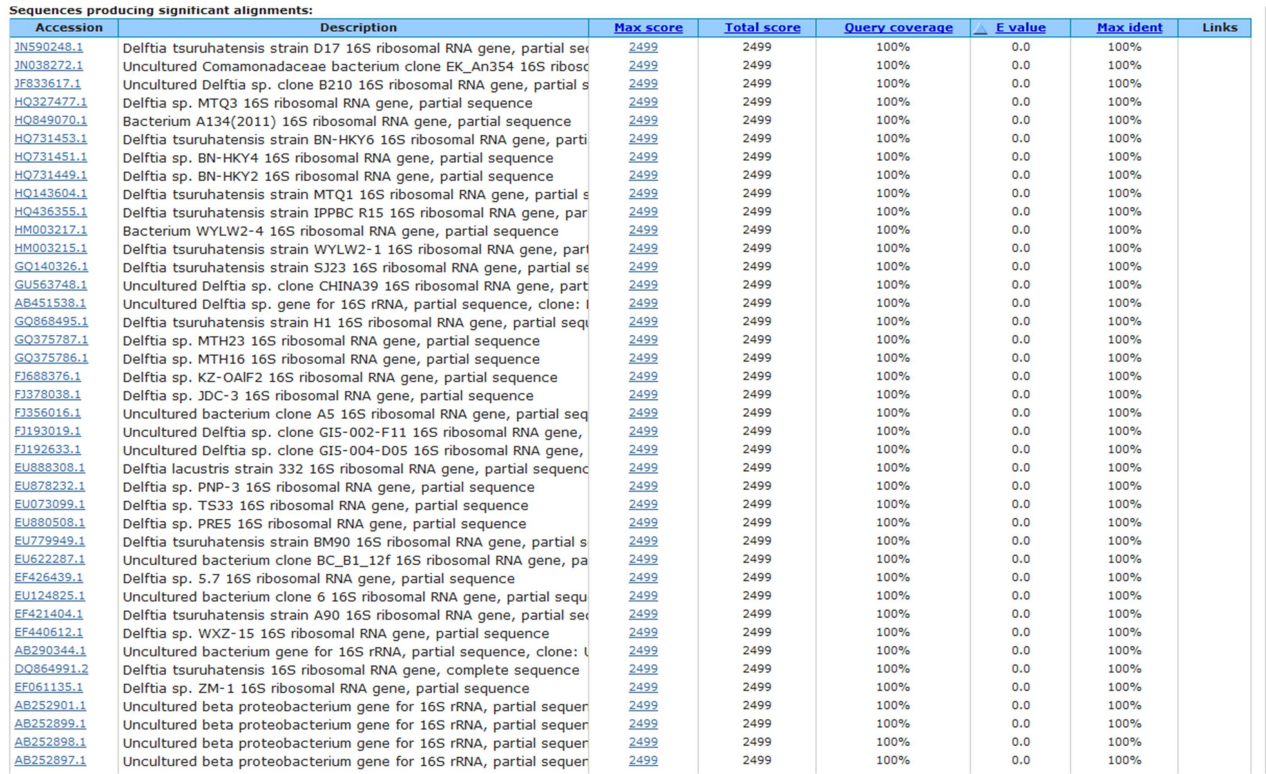

Figure 6: The culture "SK1" shows significant similarity with Delftia tsuruhatensis based on nucleotide homology

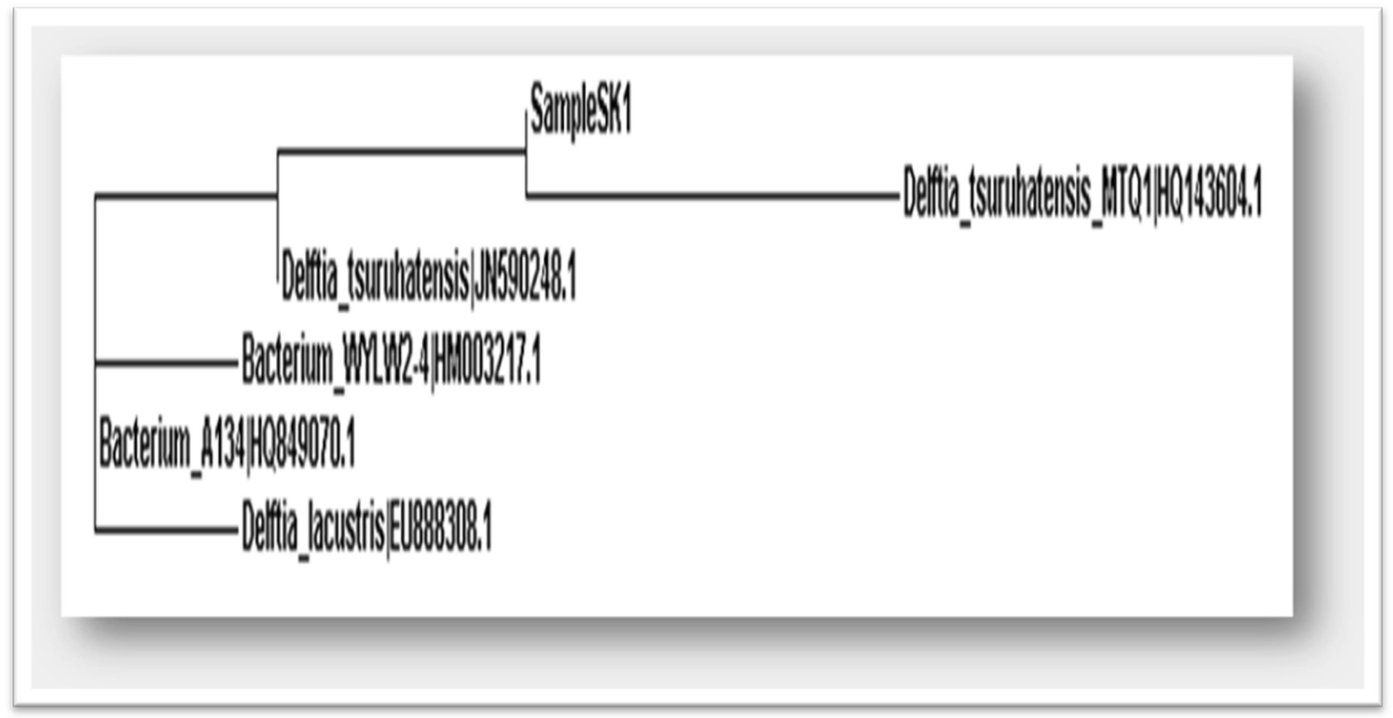

Figure 7: "SK1"- Delftia tsuruhatensis as representative of genus group based on nucleotide homology and phylogenetic analysis

\section{CONCLUSION}

From abovesaid research work, it is concluded that there was somehow correlation between conventional method and $16 \mathrm{~S}$ rDNA gene sequencing of the study isolates however isolated bacterial strains are microflora or may be microbial contaminates of water where from the sample fish i.e. Clarias batrachus (Walking Catfish) taken into the lab but they are important part of intestinal ecosystem and plays vital role in immune system of organisms and also studying the relation between Microflora and pathogenic organisms. While there are lots of prospect in the future to study the role of microflora 
of fish in different aspect for healthy and pathogen free aquaculture farming. Moreover, combination of conventional techniques and molecular approach will improve bacteriological diagnosis and allow specific and efficient way to relate microflora and pathogenic bacteria found in GI tract of Clarius batrachus, and other research in aquaculture pathology in future.

In the present research work, the study of molecular characterization of microflora helps in some or another way for understanding the risk associated with pathogenic and non-pathogenic organisms and it will also help to study the common contaminants of water isolated from the intestine of Clarius batrachus for further research in aquaculture pathology.

\section{Acknowledgement}

Finance rendered by the University Grant Commission, Western Regional office (WRO), Pune for Minor Research Project as Principal Investigator during the course of research work is duly acknowledged.

\section{REFERENCES}

[1] Ringo, E, Birbeck, $\mathrm{T} \mathrm{H}$, 1999.Intestinal Microflora of fish larvae and fry. Aquaculture Research, 30: 73-93.

[2] Cahill MM. 1990, "Bacterial flora of fishes -a review." Microbial ecology 19:21-41
[3] Andlid T, Vazquez-Juarez R, Guastafsson L, 1998. "Yeasts isolated from the Intestine of rainbon trout adhere to and gram in intestinal mucus." Molecular marine Biol. Biotech., 7 : 115 -126

[4] Asfie M. Yoshijima P. Sujata H. 2003 "Characterization of the goldfish jecal microflora by the fluorescent in situ hybridization. Method". Fisheries Sci 69: 21-26.

[5] Ahmed H, Al-Habri T, Uddin MN 2003. "Seasonal Variation in the Intestinal bacterial flora of hybrid Tilapia (Oreochromic niloticus \& Oreochromic aureus) cultured in ponds in Saudi Arabic Aquaculture" 299:33-44

[6] Ahmed H, Al-Habri T, Uddin MN, 2004. "Seasonal Variation in the Intestinal bacterial flora of hybrid Tilapia (Oreochromic niloticus \& Oreochromic aureus) cultured in ponds in Saudi Arabic Aquaculture" 299:33-44

[7] Blanch AR, Alsina M, Simon M, Jofre J .1997. "Determination of bacteria associated with reared turbot (Scophthalmus maximus) larvae". J. Applied Microbio 82 : 729-734

[8] Spanggaard B., Huber I., Nielsen J., Nielsen T., Appel. K. F., Gram L., 
2000. The Microflora a Rainbow trout: a comparison of traditional and Molecular identification. Aquaculture 182:1-15.

[9] Bairagi A, Ghosh KS, Sen AK 2002. "Enzyme producing bacterial flora isolated from fish digestive tracts". Aquaculture Int $10: 109$ 121

[10] Ringø E., Rolf Erik Olsen, Terry M Mayhew, Reidar Myklebust, 2003 Electron microscopy of the intestinal microflora of fish. Aquaculture; Volume 227, Issues 1-4, 10 November 2003, Pages 395-415.

[11] Vlkova E., Trojanova, I., Rada, V., 2006. Distribution of Bifidobacteria in the gastrointestinal tract of Calves. Folia Microbiol. 51(4): 325-328.

[12] Bergh O, Naas KE, Harboe T. 1994. "Shift in Intestinal Microflora of Atlantic halibut Carvae during first feeding." Canadian $\mathrm{J}$ fisheries Aquatic Sci 51: 1899-1903.

[13] Mohan C .V. \& Bhatta, 2002. Social and economic impact of aquatic animal health problem on aquaculture in India. Aqua. 43: 6375
[14] Das M.K., 2002. Social and economic impact of diseases in inland open-water and culturebased fisheries in India. 333-344.

[15] Balcazar JL, De Blas I, RuizZarzuela I, Vendrell D, Giiron'es O, Uuzquiz JL, 2007. 'Sequencing of variable region of the $16 \mathrm{~s} r$ RNA gene for Identificatin of lactic acid bacteria isolated from the Intestinal microbiota of healthy salmonids." Comp Inmunol., Microbial Infec. Dis 30: 111-118. 